\title{
Infectious Pancreatic Necrosis Virus Causing Clinical and Subclinical Infections in Atlantic Salmon Have Different Genetic Fingerprints
}

\author{
Stephen Mutoloki ${ }^{1 *}$, Trude B. Jøssund ${ }^{2}$, Gordon Ritchie ${ }^{2}$, Hetron M. Munang'and ${ }^{1}$ and \\ Øystein Evensen ${ }^{1}$ \\ ${ }^{1}$ Faculty of Veterinary Medicine and Biosciences, Norwegian University of Life Sciences, Oslo, Norway, ${ }^{2}$ Marine Harvest \\ ASA, Bergen, Norway
}

\section{OPEN ACCESS}

Edited by:

Jean-Christophe Avarre, Institut de Recherche pour le

Développement, France

Reviewed by:

Neil Ruane,

Marine Institute, Ireland

Pablo Conejeros,

Universidad de Valparaiso, Chile

Yoanna Eissler,

Universidad de Valparaíso, Chile

*Correspondence:

Stephen Mutolok

stephen.mutoloki@nmbu.no

Specialty section:

This article was submitted to

Aquatic Microbiology,

a section of the journal

Frontiers in Microbiology

Received: 15 June 2016 Accepted: 23 August 2016

Published: 31 August 2016

Citation:

Mutoloki S, Jøssund TB, Ritchie G, Munang'andu HM and Evensen $\varnothing$ (2016) Infectious Pancreatic Necrosis Virus Causing Clinical and Subclinical Infections in Atlantic Salmon Have

Different Genetic Fingerprints.

Front. Microbiol. 7:1393.

doi: 10.3389/fmicb.2016.01393
Infectious pancreatic necrosis virus (IPNV) is the causative agent of IPN, an important disease of salmonids. IPNV infections result in either sub-clinical or overt disease and the basis of this difference is not well-understood. The objective of the present study was to determine the VP2 gene of the virus associated with the different forms of clinical manifestation. Groups of Atlantic salmon (Salmo salar L.) reared in farms located in different IPN disease pressures were monitored from brood stock until grow-out over a 3 year period. Hatcheries $\mathrm{A} 1$ and $\mathrm{B} 1$ as well as cooperating seawater farms were located in a low disease risk area while hatcheries A2 and B2 as well as their cooperating seawater farms were in high IPN risk areas. Samples including eggs, milt, whole fry, kidney depending on the stage of production were collected during outbreaks or in apparently healthy populations where no outbreaks occurred. The virus was re-isolated in CHSE cells and the VP2 gene amplified by RT-PCR followed by sequencing. During the freshwater stage, there were no disease outbreaks at hatcheries $A 1, A 2$, and $B 1$ (except in one fish group that originated from hatchery B2), although IPNV was isolated from some of the fish groups at all 3 hatcheries. By contrast, all fish groups at hatchery B2 suffered IPN outbreaks. In seawater, only groups of fish originating from hatchery A1 had no IPN outbreaks albeit virus being isolated from the fish. On the other hand, fish originating from hatcheries A2, B1, and B2 experienced outbreaks in seawater. The VP2 amino acid fingerprint of the virus associated with subclinical infections from A1 and co-operating seawater sites was V64A137P217T221A247N252S281D282E319. By contrast, all virus isolates associated with clinical infections had the motif I64T137T217A221T247V252T281N282A319, where underlined amino acids represent the avirulent and highly virulent motif, respectively. Phylogenetic analysis of amino acid sequences showed 2 clades, one of isolates associated with subclinical infections (from A1 and cooperating seawater farms) and the other of isolates from fish with overt disease (all other sites). Furthermore, the clustering pattern of isolates suggests more circulation of virus within fish groups rather than between them.

Keywords: salmon, infectious pancreatic necrosis virus, genotype, clinical, subclinical 


\section{INTRODUCTION}

Infectious pancreatic necrosis (IPN) remains one of the most important viral diseases of farmed salmonids in Norway. It is caused by the IPN virus (IPNV), a non-enveloped, double stranded RNA virus. The virus is a prototype in the genus Aquabirnavirus and belongs to the family Birnaviridae. It affects Atlantic salmon at all stages of production especially at startfeeding of fry, in fingerlings and parr during the fresh water stage as well as in post-smolts 3-4 weeks following sea water transfer (Roberts and Pearson, 2005).

In general, IPNV transmission occurs horizontally (Gregory et al., 2003). Although vertical transmission has been demonstrated in rainbow trout (Oncorhynchus mykiss; Dorson and Torchy, 1985), it has not been definitively proven in Atlantic salmon (Salmo salar L.). Nevertheless, adsorption of the virus to the surface membrane of sperms and egg fluid would be one method by which it occurs (Wolf et al., 1963; Mulcahy and Pascho, 1984; Reno, 1999; Smail and Munro, 2008). Outbreaks of IPN in fry at start-feeding are thought to be as a result of this method of transmission (Roberts and Pearson, 2005). Survivors of IPNV infection become persistently infected and are sources of infection to naïve fish (Roberts and Pearson, 2005). The ability of the virus to survive in the environment and in alternative hosts (Mulcahy and Pascho, 1984; Rimstad, 2003; Gregory et al., 2007) ensures that the infection is perpetuated through subsequent stocks of fish at particular sites.

Predisposing factors for disease outbreaks are not known in detail although host-related, virus-associated, and environment factors are all important. For hosts, differences in the susceptibility between fish families (Okamoto et al., 1993) point to genetic variation playing a role. This has recently been demonstrated by the introduction of QTL fish that has shown resistance against the disease (Houston et al., 2008). For the virus, previous studies where Norwegian IPNV isolates obtained from Atlantic salmon during field outbreaks were used to experimentally challenge fish showed that certain amino acids in the capsid protein are associated with virulence (Santi et al., 2004). By using reverse genetics, these amino acids were mapped to positions 217 , and 221 , with highly virulent isolates encoding the $\mathrm{T}_{217} \mathrm{~A}_{221}$ motif while avirulent isolates had $\mathrm{P}_{217} \mathrm{~T}_{221}$ (Song et al., 2005). Despite this knowledge, traits of IPNV associated with clinical or subclinical infections of fish in fresh and seawater under field conditions have remained unclearly documented, with some authors reporting mortalities associated with IPNV having the $\mathrm{P}_{217} \mathrm{~T}_{221}$ motif (Bain et al., 2008). The purpose of the present study was to investigate genetic fingerprints of field strains of IPNV associated with clinical or asymptomatic disease. A traceback study was used to determine whether outbreaks of IPN or absences thereof, in the field, were linked to specific amino acids on the major capsid protein of the virus. IPNV from production lines (broodstations, hatcheries, seawater sites) reported to have had major or minor IPN outbreaks were targeted and genetic sequences of the capsid protein (VP2) of IPNV from infected fish were examined. The VP2 protein is the major structural protein encoded by the large open reading frame of segment A (Macdonald and Dobos, 1981; Duncan et al., 1987) and comprises proteins 1-442 of the polypeptide (Galloux et al., 2004). It was preferred for this analysis because of its implication in virulence, serotype specificity, and immunogenicity (Heppell et al., 1993; Frost et al., 1995; Bruslind and Reno, 2000; Shivappa et al., 2004; Song et al., 2005).

\section{MATERIALS AND METHODS}

This study was approved by the Norwegian Animal Research Authority. Prior to sampling, the fish was anesthetized with Finquel $^{\circledR}(100 \mathrm{mg} / \mathrm{L})$ in order to prevent suffering.

\section{Study Design and Animals Used}

The present study was undertaken in the mid Northwestern coast of Norway over a 3-year period. The fish farms targeted were categorized as either high or low IPN risk on the basis of the number of outbreaks that had occurred during the previous 3 years prior to the onset of the present study. Fish farms that had had at least three outbreaks over 3 seasons prior to onset of the study were categorized as being in the high-risk group while those with $0-2$ outbreaks were considered as low risk. To a large extent, samples were collected from each developmental stage in different groups of fish. Here "group" implies fish hatching from one batch of eggs and subjected to the same production treatment until grow-out at sea. Hatcheries and freshwater sites are used interchangeably. Clinical infections refer to fish exhibiting signs of IPN and following sampling, were confirmed diseased by the National Veterinary Institute in Norway.

At the start of the study, hatcheries A1 and B1 and cooperating seawater farms, i.e., A1-1 to A1-3 and B1-1 to B1-3, respectively were designated as being in the low IPN risk category (Figure 1). Hatcheries A2 and B2 as well as the co-operating seawater farms were in the high-risk category. One fish group sampled at one of the seawater farms (A2-4, Figure 1) originated from hatchery $\mathrm{A} 3$ that was not part of the hatcheries included in this study.

The main source of fertilized eggs for the hatcheries (A1 and $\mathrm{A} 2$ ) and (B1 and B2) were brood stations A and B, respectively (Figure 1). In addition, hatcheries $A 1$ received fertilized eggs from another brood station $\mathrm{C}$.

Brood stations $\mathrm{A}$ and $\mathrm{C}$ belonged to the same organization and therefore were subject to similar management practices while brood station B belonged to a different company and had a different management practice. Similarly, hatcheries/freshwater sites A1 and A2 and seawater farms A1-1 to A1-3 and A2-1 to A2-4 belonged to the same organization as brood stations $\mathrm{A}$ and $\mathrm{C}$. This cooperation is the basis for grouping hatcheries A1 with A2 and their cooperating seawater farms in Figure 1. Hatcheries B1 and B2 belonged to another company cooperating with corresponding seawater farms designated B. Finally, all the fish in this study were reared according to standard fish farming practices in Norway.

During the freshwater stage, fingerlings, and parr were sorted according to class sizes and reared as units identifiable as groups. This was done several times at all sites. The fish were cultivated 


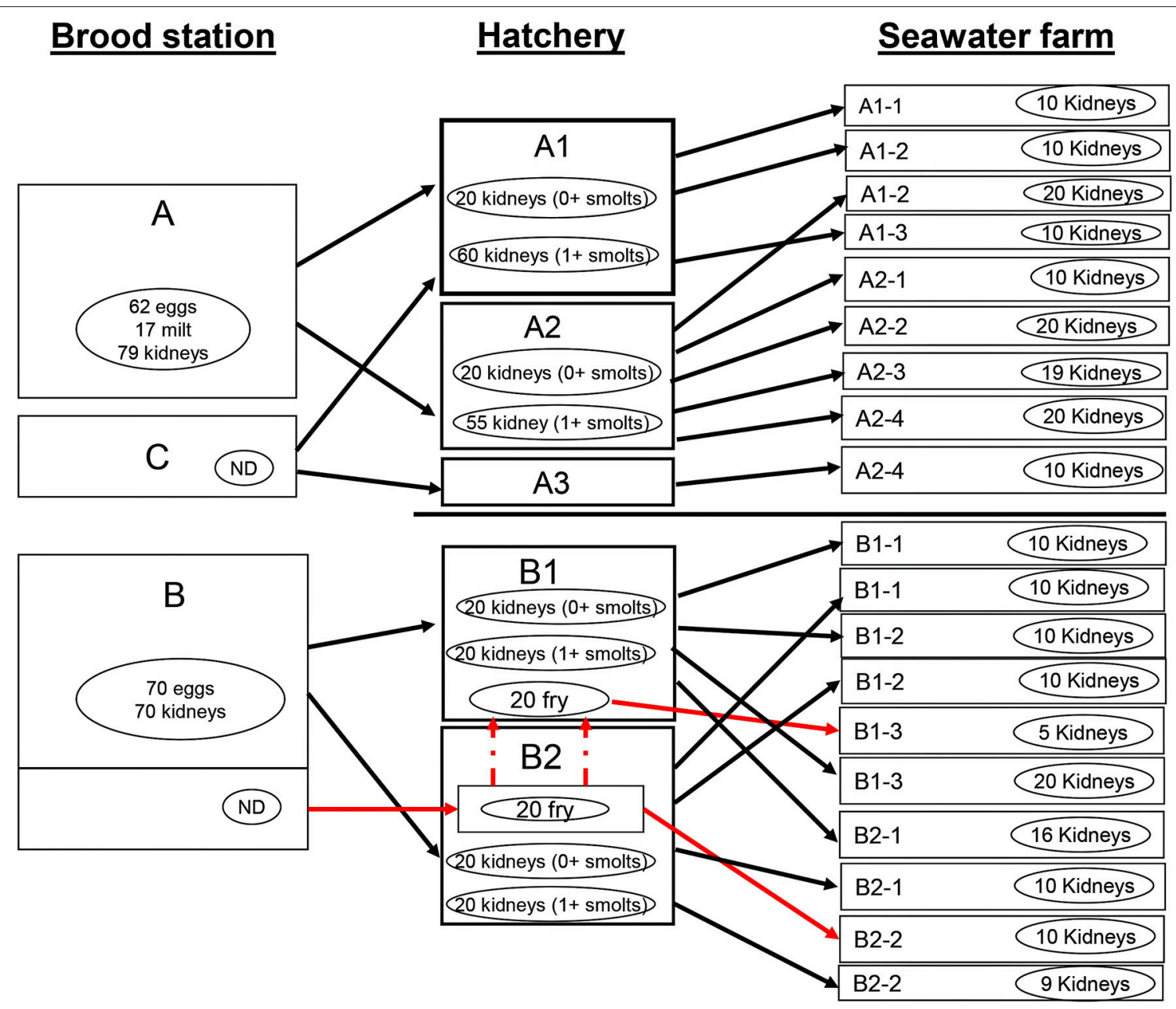

FIGURE 1 | Study design and flow of breeding materials from fertilized eggs and fish in broodstations to grow out farms. Type of samples and the numbers collected at each stage are provided for each group of fish. Each rectangle represents an independent fish group and arrows link the groups at different stages. ND, no samples collected; red dotted line, infected fry transfer at freshwater stage.

both as in-season (S1) and also out of season (S0). Accordingly, smolts were put to sea twice, as $1+$ smolts (after 18 months in fresh water) and $0+$ smolts (10 months in fresh water), respectively.

\section{Sample Collections}

Samples were collected at different stages of production as described below.

\section{Brood Stations}

Following stripping of eggs and milt from breeders for each batch, samples of eggs and milt were taken. Breeders were sacrificed prior to sampling of head kidney. At brood station A, the batches from which samples were collected were chosen randomly. The numbers of samples are shown in Figure 1. At brood station B, only eggs as well as organ samples from the donors were collected. No samples were collected from stations C.
The handling of samples following collection was as follows: eggs and milt were frozen immediately after collection and transported to the Norwegian University of Life Sciences; the kidney samples from brood fish were preserved in serum-free transport media consisting of Leibovitz's L-15 medium (Sigma Aldrich) supplemented with $50 \mu \mathrm{g} \mathrm{ml}^{-1}$ Gentamycin.

\section{Hatcheries/Freshwater Stage}

Sampling was done during IPN disease outbreaks, targeting moribund or dying fish. As shown in the study design (Figure 1), samples from freshwater sites were collected from the same batches as eggs and milt were sampled. Fry were collected whole while kidney samples were collected from larger fish and preserved in transport medium during transportation. In the absence of outbreaks, randomly selected parr were sampled. As already stated, the fish were sorted several times at this stage and therefore mixed with fish from different units within the same group thereby expanding/diluting the pool. 


\section{Seawater Farms}

For clarity, the first two letters in the name of the seawater farms are derived from the hatchery that they primarily co-operated with (Figure 1). Each farm should be viewed as an independent entity.

The same procedure as in freshwater was used to sample post-smolts/growers in seawater (Figure 1) targeting the same groups. The IPN disease in all outbreaks was provisionally diagnosed on the basis of clinical signs and confirmed by immunohistochemistry at the National Veterinary Institute (Trondheim).

\section{Virus Isolation by Cell Culture}

Chinook salmon embryo cells (CHSE-214, ATCC CRL-1681) were used for screening of IPNV. The cells were incubated at $20^{\circ} \mathrm{C}$ and were routinely maintained in Leibovitz's L-15 medium supplemented with 5\% FBS and $50 \mu \mathrm{l}^{-1}$ gentamycin.

To prepare the samples for inoculation, Atlantic salmon eggs were homogenized in a stomacher (IUL Instrument) for $1 \mathrm{~min}$, diluted by adding an equal amount (w/v) of transport medium followed by centrifugation at $2500 \times \mathrm{g}$ for $10 \mathrm{~min}$ at $4^{\circ} \mathrm{C}$. Thereafter the supernatant was harvested and stored at $-70^{\circ} \mathrm{C}$ until required. Kidney samples were homogenized the same way in serum-free L-15 medium supplemented with $50 \mu \mathrm{l}^{-1}$ Gentamycin $(1: 10 \mathrm{w} / \mathrm{v})$. The milt was prepared by centrifugation at $2500 \mathrm{rpm}$ for $10 \mathrm{~min}$ at $4^{\circ} \mathrm{C}$, harvesting the supernatant in an equal volume of transport medium.

The samples were inoculated individually, in two dilutions (1:10 and 1:100) on confluent CHSE cells seeded on 24 wells plates (Sigma). The presence or absence of virus was established by the presence/absence of cytopathic effect (CPE) after two passages. Three randomly selected positive samples per group from each site were then used as starting material for genotyping of IPNV-VP2 gene.

\section{RNA Extraction, Sequencing, and Genotyping}

The cell culture supernatants were first clarified by centrifugation at $2500 \times \mathrm{g}$ for $10 \mathrm{~min}$ at $4^{\circ} \mathrm{C}$. The viral RNA isolation kit (Qiagen) was used to isolate viral RNA starting with $140 \mu \mathrm{l}$ of the supernatant, according to the manufacturer's instructions. Amplification of VP2 gene was done by PCR using gene-specific primers A-sp1-24F and A-sp-1696R (Table 1) in a one-step RTPCR (Qiagen). PCR products were then separated by using 1\% Agarose gel electrophoresis and extracted using the QIAquick Gel Extraction Kit (Qiagen). Sequencing was done by direct sequencing of PCR products on a commercial basis at MWG Biotech (Germany) using 3 primers A-sp59F, A-sp500F, and A-sp1689R (Table 1) as previously done (Santi et al., 2004). The sequence data was assembled using Vector NTI software (Invitrogen). Analysis and translation of sequences was done by using SDSC Biology workbench 3.2 (workbench.sdsc.edu). The CLC Main Workbench 6.0 (www.clcbio.com) and Mega7 software (Kumar et al., 2016) were used for sequence alignment and phylogenetic and evolutionary analyses. The phylogenetic tree of the major capsid protein was inferred by the Maximum
TABLE 1 | Gene-specific primers for infectious pancreatic necrosis virus used in the present study.

\begin{tabular}{llc}
\hline Name & Sequence & Nucleotide no. \\
\hline A-sp1-24F & GGAAAGAGAGTTTCAACGTTAGTG & $1-24$ \\
A-sp1696R & GGACTCCAGCCTGTTCTTGAG & 1696-1676 \\
A-sp59F & TCTCCGTCGATGGCGAAAG & $59-77$ \\
A-sp500F & GAGTCACAGTCCTGAATC & $500-517$ \\
A-sp1689R & AGCCTGTTCTTGAGGGCTC & $1689-1671$ \\
\hline
\end{tabular}

Likelihood method, bootstrapped 1000 times based on the JTT+G matrix-based model (Jones et al., 1992).

\section{Structural Analysis of the VP2 Capsid}

To gain insight into the structural layout of amino acids influencing the antigenic variabilities detected from the study sites, the SWISS model workspace (Arnold et al., 2006) and Pymol version 99 (PyMol, 2012) were used to align the sequences and to address the structural layout of these resides as well as to determine their potential influence on the clinical and subclinical conditions observed from the study sites, respectively.

\section{RESULTS}

A total of 910 samples including kidneys, eggs, milt, and whole fry from 3 brood stations, 5 hatcheries, and 12 sea water sites were processed throughout the study period. Tissue samples collected from brood fish, eggs, and milt at brood stations A and B yielded negative IPNV isolation. As already mentioned, no samples were collected from brood fish at station C. IPNV was isolated from fish in both hatcheries and seawater sites. The VP2 gene of the virus was amplified by PCR and sequenced. The sequence information as well as the source of samples is presented in Table 2.

\section{Low IPN Disease Risk Category} Hatchery A1 and Co-operating Seawater Farms A1-1 to $A 1-3$

No disease outbreaks were observed at hatchery A1 although IPNV was isolated from apparently healthy fish (Figure 2A). The prevalence of infection in fish was estimated at $10 \%$ and the virulence motif (Santi et al., 2004) was found to be $\mathrm{P}_{217} \mathrm{~T}_{221}$ (PT) in all cases.

No outbreaks were observed at seawater farms A1-1 to A13 receiving smolts from hatchery A1. IPNV was isolated from apparently healthy individuals in seawater but this time the prevalence of infection was 50-90\% (Figure 2A). Seawater farm A1-2 received smolts from hatchery $\mathrm{A} 2$ in addition to that from A1 and it is the group from A2 that an IPN outbreak was experienced. The prevalence of infection in this group was $100 \%$ and the motif of the virus was $\mathrm{T}_{217} \mathrm{~A}_{22}$ (TA), similar to that found at hatchery A2. 
TABLE 2 | Samples from which infectious pancreatic virus was isolated in the present study.

\begin{tabular}{|c|c|c|c|}
\hline Sample & Source & Fish type & Genbank accession no. \\
\hline A1_32 & $\mathrm{A} 1$ & Parr & KX355261 \\
\hline B1-3_36 & B1-3 & Smolt & KX355260 \\
\hline A1-3_53 & A1-3 & Smolt & KX355259 \\
\hline A1-1_9 & $\mathrm{A} 1-1$ & Smolt & KX355258 \\
\hline A1_51 & $\mathrm{A} 1$ & Smolt & KX355257 \\
\hline A1-2_4 & A1-2 & Smolt & KX355256 \\
\hline A1_48 & A1 & Parr & KX355255 \\
\hline A1-3_54 & A1-3 & Smolt & KX355254 \\
\hline A1-3_28 & A1-3 & Smolt & KX355253 \\
\hline A1-2_6 & A1-2 & Smolt & KX355252 \\
\hline B1-3_37 & $\mathrm{B} 1-3$ & Smolt & KX355251 \\
\hline A2-1_30 & A2-1 & Smolt & KX355250 \\
\hline B2-1_5 & $\mathrm{B} 2-1$ & Smolt & KX355249 \\
\hline A2-4_41 & $\mathrm{A} 2-4$ & Smolt & KX355248 \\
\hline A2-4_40 & A2-4 & Smolt & KX355247 \\
\hline A1-2_1 & A1-2 & Smolt & KX355246 \\
\hline A2-4_46 & A2-4 & Smolt & KX355245 \\
\hline B2-2_39 & B2-2 & Smolt & KX355244 \\
\hline A2-4_38 & $\mathrm{A} 2-4$ & Smolt & KX355243 \\
\hline B1-1_43 & B1-1 & Smolt & KX355242 \\
\hline B1_47 & B1 & Fry & KX355241 \\
\hline B2-2_33 & B2-2 & Smolt & KX355240 \\
\hline B1-1_44 & $\mathrm{B} 1-1$ & Smolt & KX355239 \\
\hline B1-3_8 & B1-3 & Smolt & KX355238 \\
\hline A2_29 & A2 & Fry & KX355237 \\
\hline A2-2_45 & A2-2 & Smolt & KX355236 \\
\hline B2-2_42 & B2-2 & Smolt & KX355235 \\
\hline B2-2_34 & B2-2 & Smolt & KX355234 \\
\hline B1-2_31 & B1-2 & Smolt & KX355233 \\
\hline B2_52 & B2 & Parr & KX355232 \\
\hline B2_50 & B2 & Parr & KX355231 \\
\hline B2_26 & B2 & Fry & KX355230 \\
\hline B2_27 & B2 & Fry & KX355229 \\
\hline B1-3_7 & B1-3 & Smolt & KX355228 \\
\hline B1-3_35 & B1-3 & Smolt & KX355227 \\
\hline B1-3_3 & B1-3 & Smolt & KX355226 \\
\hline A1_2 & $\mathrm{A} 1$ & Parr & KX355225 \\
\hline B1_49 & B1 & Fry & KX355224 \\
\hline B2-2_18 & B2-2 & Smolt & KX355223 \\
\hline B2-2_15 & B2-2 & Smolt & KX355222 \\
\hline A1-2_14 & $\mathrm{A} 1-2$ & Smolt & KX355221 \\
\hline A2-3_13 & A2-3 & Smolt & KX355220 \\
\hline A1-2_12 & A1-2 & Smolt & KX355219 \\
\hline A1-2_11 & A1-2 & Smolt & KX355218 \\
\hline B1-1_16 & B1-1 & Smolt & KX355217 \\
\hline B1-1_17 & B1-1 & Smolt & KX355216 \\
\hline B1-3_10 & B1-3 & Smolt & KX355215 \\
\hline
\end{tabular}

\section{Hatchery B1 and Co-operation Seawater Sites and B1-1 to B1-3}

At hatchery B1, no disease outbreaks were observed except in one fish group (Figure 2B). The outbreak was in a group of fry that had been transferred from a high-risk hatchery $\mathrm{B} 2$ where the mortality was $31 \%$. The mortality in fry at B1 was $62 \%$ and the prevalence of infection $100 \%$. The virulence motif was TA, similar to that found at the hatchery B2.

For seawater farms B1-1 to B1-3, IPN outbreaks were observed in all except one farm (B1-2), irrespective of whether or not IPNV had been isolated from the fish group during the freshwater stage. The prevalence of infection in all groups ranged from 20 to $100 \%$ while mortalities were between 2 and 5\% (Figure 2B). The virulence motif of the virus was $\mathrm{TA}$, similar to the strain isolated from the fish groups at hatcheries B1 and B2 where outbreaks were observed. Seawater farms B1-1 to B1-3 received smolts from B2 in addition to the supply from B1 (Figure 2B). Surprisingly, only one farm (B1-2) as mentioned did not experience any IPN outbreak.

\section{High IPN Disease Risk Category Hatchery A2 and Co-operating Seawater Farms A2-1 to A2-4}

Although hatchery A2 was categorized as high risk, there were in fact no disease outbreaks during the study period. In two fish groups however, $\sim 30 \%$ of the fish sampled were infected with IPNV, with virulence motif of TA while no IPNV was isolated from 3 out of the 5 groups (Figure 2A).

When smolts were transferred to seawater farms, IPNV was isolated from all fish groups and outbreaks were experienced in all except one group at farm A2-1. In this group, the prevalence of infection was $20 \%$ as opposed to the others where it ranged from 85 to 100\% (Figure 2A). The virulence motif of the virus in all cases was TA, similar to that of the hatchery A2 where the fish originated. An extra group of fish from an external hatchery (A3) was included in the sampling plan at farm A2-4. This group was also infected with the TA variant of IPNV and had a prevalence of 100 and $13 \%$ mortality.

\section{Hatchery B2 and Co-operating Seawater Farms B2-1 and $\mathrm{B} 2-2$}

The hatchery B2 experienced the highest number of outbreaks, mortalities and prevalence. All fish groups had IPN outbreaks. The prevalence of infection in all groups was $100 \%$ and the virulence motif was TA while mortalities ranged from 5 to $31 \%$ (Figure 2B).

Hatchery B2 co-operated primarily with only two seawater farms (B2-1 and B2-2) targeted in this study and totally 4 fish groups at these sites were examined. One of the sites (B2-1) received smolts from B1 in addition (Figure $2 \mathbf{B}$ ). These groups of fish became infected at sea and the prevalence was $75 \%$ (Figure 2B). Although there was an outbreak in this group, mortality figures were unfortunately not available.

At farm B2-2, the two groups examined had 30 and 33\% IPNV prevalence and 2 and 5\% mortalities, respectively. The variant of the virus was TA.

\section{Genomic Analysis of the VP2 Genes from Different Isolates}

Translated amino acid sequence alignments of virus isolates in this study revealed that isolates associated with clinical 
A

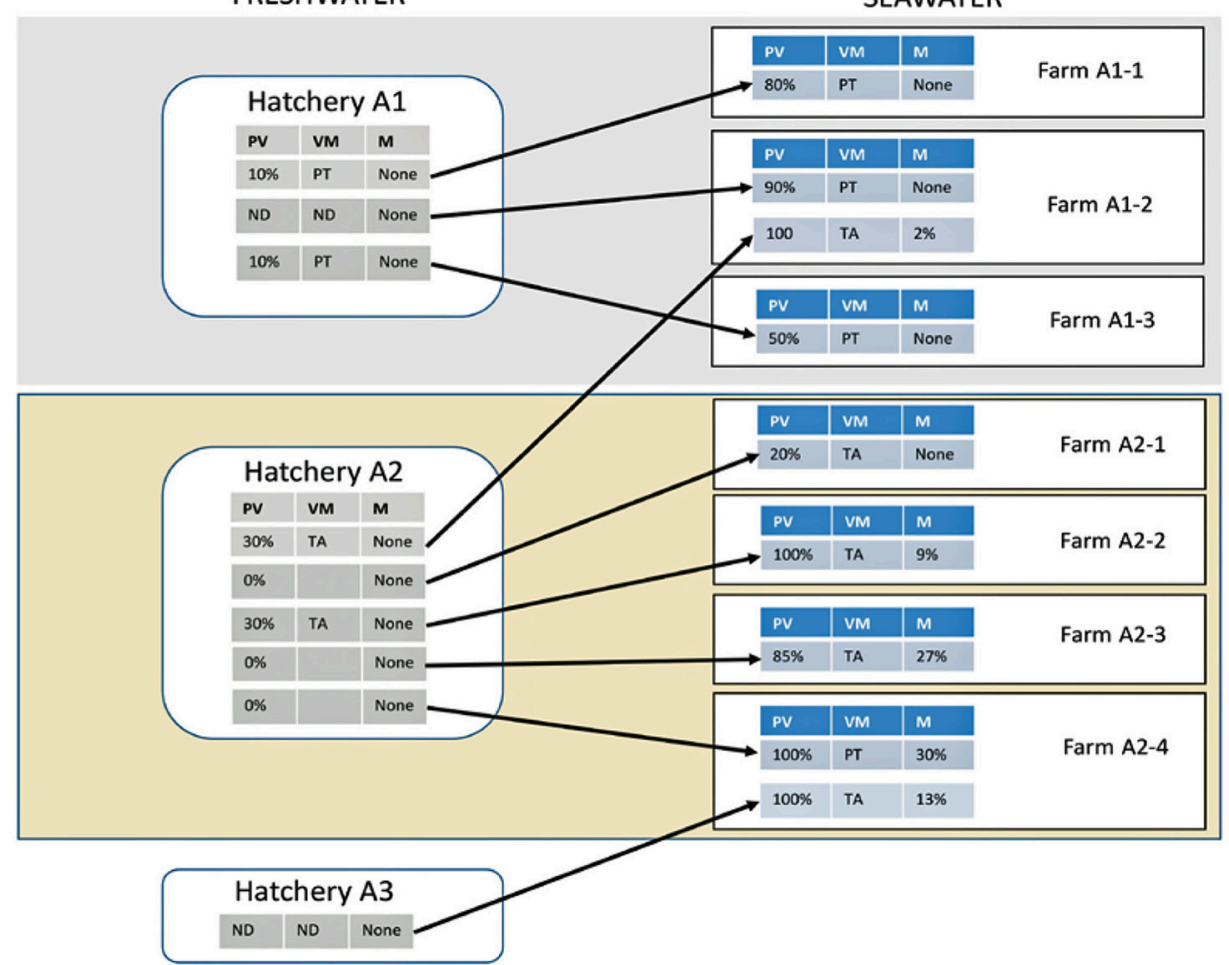

B

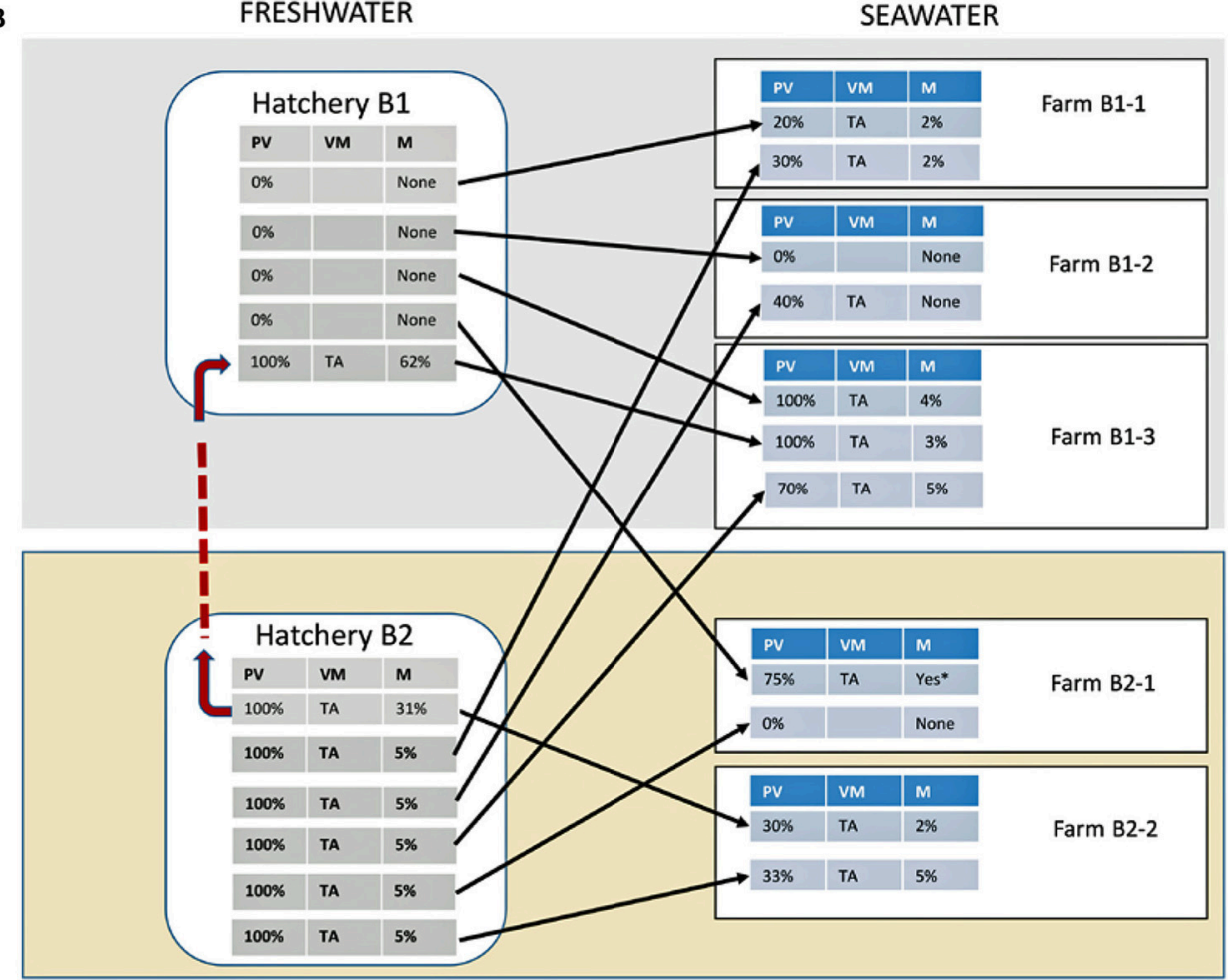

FIGURE 2 | Infectious pancreatic necrosis virus (IPNV) infections and mortalities in different groups of Atlantic salmon in hatcheries and seawater farms. (A) Hatcheries and seawater sites that received breeding materials primarily from brood station A and (B) Hatcheries and seawater sites that received breeding materials primarily from brood station B. Each block (rectangle) within a hatchery/farm represents an independent fish group and arrows connect the groups at different stages. PV, \% prevalence of infection; VM, virulence motif represented by amino acid residues 217 and 221 of the VP2 protein; M, mortality due to IPNV; ND, No samples collected; red dotted line, infected fry transfer at freshwater stage; *Mortality figures not available. Gray and yellow background colors represent the primary setup of hatcheries and seawater farms cooperation. 


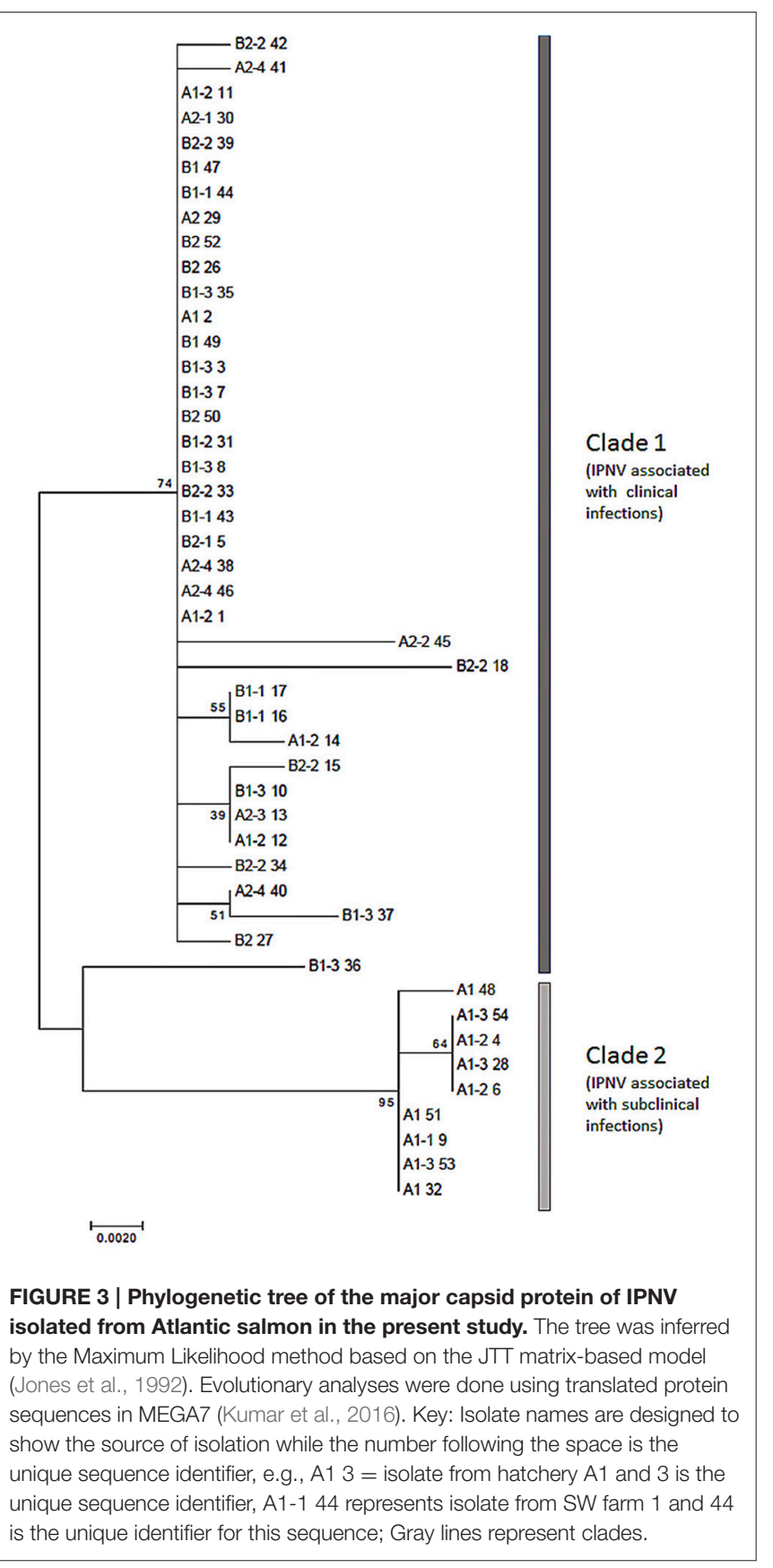

and subclinical infections had different genetic fingerprints in the capsid protein (VP2). Isolates associated with subclinical infections had a consensus amino acid motif of $\mathrm{V}_{64} \mathrm{~A}_{137} \mathrm{P}_{217} \mathrm{~T}_{221} \mathrm{~A}_{247} \mathrm{~N}_{252} \mathrm{~S}_{281} \mathrm{D}_{282} \mathrm{E}_{319}$ while those from fish with clinical had $\mathrm{I}_{64} \mathrm{~T}_{137} \mathrm{~T}_{217} \mathrm{~A}_{221} \mathrm{~T}_{247} \mathrm{~V}_{252} \mathrm{~T}_{281} \mathrm{~N}_{282} \mathrm{~A}_{319}$.

Phylogenetically, the isolates clustered into 2 main clades (Figure 3). Clade 1 constituted isolates associated with overt disease in Atlantic salmon. By contrast, Clade 2 was composed of isolates from hatchery A1 and associated seawater sites, of fish that were infected with the isolates inducing subclinical forms.

\section{Structural Analysis of VP2 Capsid of Different Isolates}

Figure 4 shows the positions of amino acid residues on the VP2 subviral particle (SVP). Note that residues V64I and A137T are located in the B-domain of the SVP while residues $\mathrm{T}_{217} \mathrm{P}$ and $\mathrm{A}_{221} \mathrm{~T}$ are on loop $\mathrm{P}_{\mathrm{BC}}, \mathrm{T}_{247} \mathrm{~A}$, and $\mathrm{V}_{252} \mathrm{~N}$ are on $\mathrm{P}_{\mathrm{DE}}, \mathrm{T}_{281} \mathrm{~S}$, and $\mathrm{N}_{282} \mathrm{D}$ on $\mathrm{P}_{\mathrm{FG}}$ while $\mathrm{A}_{319} \mathrm{E}$ is on $\mathrm{P}_{\mathrm{HI}}$ of the hypervariable region (HVR) in the P-domain of the VP2 capsid.

\section{DISCUSSION}

The findings of the present study demonstrate that IPNV causing clinical and subclinical forms of infections under field conditions have specific genetic fingerprints. Subclinical infections were associated with a $\mathrm{V}_{64} \mathrm{~A}_{137} \mathrm{P}_{217} \mathrm{~T}_{221} \mathrm{~A}_{247} \mathrm{~N}_{252} \mathrm{~S}_{281} \mathrm{D}_{282} \mathrm{E}_{319}$ (PT) fingerprint on the major capsid protein (VP2) while isolates associated with overt disease had the fingerprint $\mathrm{I}_{64} \mathrm{~T}_{137} \mathrm{~T}_{217} \mathrm{~A}_{221} \mathrm{~T}_{247} \mathrm{~V}_{252} \mathrm{~T}_{281} \mathrm{~N}_{282} \mathrm{~A}_{319}$ (TA). Fish at hatchery A1 and corresponding seawater farms A1-1 to A1-3 that received smolts from this hatchery were all infected with the former, and no mortalities were experienced irrespective of the degree of prevalence of infection (Figure 2A). On the other hand, all fish groups with IPN disease outbreaks were infected with the TA variant (Figure 2). Previous studies have shown that virulent and avirulent strains of IPNV have specific amino acids in the VP2 protein represented by motifs $\mathrm{T}_{217} \mathrm{~A}_{221}$ and $\mathrm{P}_{217} \mathrm{~T}_{221}$, respectively (Santi et al., 2004; Song et al., 2005). These two positions are part of the genetic fingerprint reported here and our findings are consistent with these reports.

The most affected hatchery with IPN in this study was B2 where virtually all groups examined experienced outbreaks (Figure 2). Mortalities due to IPN persisted in most of the groups following transfer to seawater suggesting that infections were carried along as previously reported by others (Roberts and Pearson, 2005). Interestingly, the prevalence of infection in all groups decreased from fresh to seawater. In two groups (B12 and B2-1), no mortalities were experienced in seawater while in one (B2-1) even the virus could not be detected suggesting that the fish has shed it off completely. It is believed that fish develop resistance to IPNV infection with age and our present findings support this view (Munro and Midtlyng, 2011). The differences in the resistance acquired between groups in this study suggests that other factors, such as the environment also contributes to the outcome of infections between sites (Munro and Midtlyng, 2011).

At hatcheries A2 and B1, most of the fish groups were not infected with IPNV and yet when transferred to sea, almost all groups developed IPN with high prevalence (Figure 2). Furthermore, fish groups from hatchery A2 experienced high mortalities (9-30\%) following seawater transfer while only $2-4 \%$ mortalities were observed in groups from B1. The patterns of infection of fish following seawater transfer points toward seawater sites being reservoirs of IPNV (Murray et al., 2003) while differences in mortalities suggest that other factors such as environment play a role in the severity of infections and further studies should be conducted to elucidate these. 

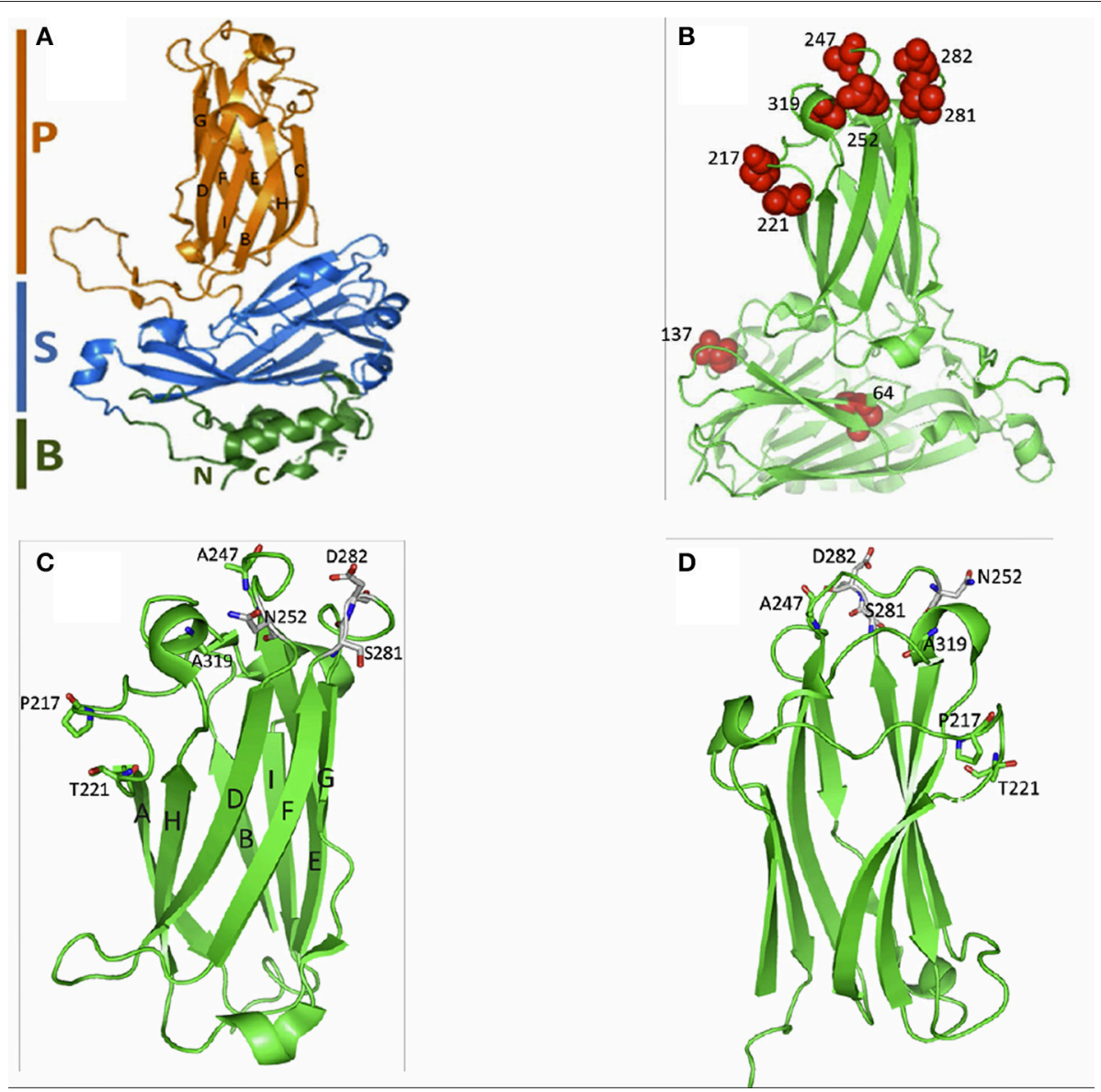

FIGURE 4 | Subviral particle (SVP) of the VP2 capsid for IPNV. (A) Shows the SVP divided into the P-domain (magenta) made of the $\beta$-sheet that supports the surface loops that form the hypervariable region (HVR), S-domain (blue) that form the shell of the capsid, and the B-domain (green) that form of the base made of the $\mathrm{N}$ - and C-termini. (B) Shows the position of the residues linked to clinical and subclinical forms of IPNV infection (red balls). Note that positions V64I and A137T are located in the B-domain while T217P and A221T on loop $P_{B C}$, residues T247A and V252N on $P_{D E}$, residues T281S and N282D on $P_{F G}$ and A319E on $P_{H I}$ in the surface loops of the HVR in the P-domain. (C) Shows the P-domain having the $\beta$-sheets supporting the surface loops of the HVR. The structural layout of residues T217, A221T, T247, N252, S281, D282 and A319 are shown as sticks projecting out of the surface loops of the HVR. (D) Shows the P-domain at 1800 turn of (C) All figures were generated in Pymol v99 (PyMol, 2012) using the 3IDE template (Coulibaly et al., 2010) on the SWISS model workspace (Arnold et al., 2006).

Being an RNA virus, IPNV lacks the proofreading ability inherent of DNA polymerases and is thus prone to mutations during replication. Hsu and colleagues showed that this virus exists as a quasi-species (Hsu et al., 1995). This is also reflected in the heterogeneity of the isolates obtained in this study (Figure 3). Inadvertently, the different variants of IPNV replication have different fitnesses. One of the traits of the highly virulent (TA) isolate is the superior replication capacity over the less virulent (TT) mutant (Gadan et al., 2013), although this was less so when compared with the PT isolate (Gamil et al., 2015). In another study, the TA variant showed superior capacity to lyse cells compared to the PT variant (Gamil et al., 2015). In support of this observation, the prevalence of the TA isolates in this study compared to their PT counterparts in naïve fish (hatcheries A2, B1, and B2 vs. A1, Figure 2) was higher. Although the amount of virus in individual fish was not measured, it is tempting to speculate that the ability of the TA isolates to spread between fish is related to their efficiency in cell lysis. The dynamics of virus infections in fish during the seawater stage gives a less obvious pattern given that the source of infection could have been either during the freshwater stage, seawater or both. What is interesting though was the general trend whereby low prevalence during the freshwater stage resulted in high prevalence during the seawater stage and vice versa (Figure 2). To some extent, the levels of mortality also reflect this observation. Whether low to high prevalence in fish from fresh- to seawater is a function of the number of susceptible individuals at sea should be a subject for further studies. Similarly, the mechanism by which fish gain resistance to IPN relative to age should also be addressed.

In terms of structural layout, it is interesting to note that P217T, T221A A247T, N252V, S281T, D282N, and E319A are located on the surface loops of the VP2-HVR (Figure 4). Based on observations made from our previous studies as well as observation made by other scientists, residues strategically located on the exterior surface of the HVR of the VP2 capsid significantly influence the virulence and antigenic properties of 
IPNV (Santi et al., 2004; Song et al., 2005; Coulibaly et al., 2010; Gadan et al., 2013). Although we did not determine the exact mechanism on how different amino acids found on the VP2-HVR influence the clinical and subclinical conditions of IPNV, studies done for other viruses have shown that motifs with high binding potential lead to reduced efficiency on the release of viruses from bound cell receptors resulting in persistent or subclinical infections (Palese et al., 1974; Bauer et al., 1995; Liu et al., 1995). On the contrary, motifs with low binding avidity result in quick virus release resulting in rapid replication culminating in clinical disease (Palese et al., 1974; Bauer et al., 1995; Liu et al., 1995). In our previous studies (Gadan et al., 2013), we observed that having a Threonine at position 221 on the VP2 capsid of IPNV led to reduced virus replication and yet a mutation to an alanine on the same position led to $>1000$-fold increase in virus replication. It is highly likely that a mutation from threonine, which has a high binding affinity for cell receptors (Betts and Russell, 2003), to an alanine which is less reactive reduces the binding avidity of the virus to cell receptors leading to increased virus release and replication. Therefore, it is likely that differences in the binding avidity of different residues found on the VP2-HVR could account for differences in clinical and subclinical forms of IPNV infections.

The absence of virus at brood stations and its isolation in different fish groups in fresh- or seawater sites (Figure 2) demonstrates that as already mentioned, fresh and seawater sites targeted in this study are contaminated with IPNV. This is consistent with a previous report and supports the view that both fresh and seawater sites are important sources of virus infections for fish (Murray et al., 2003). Furthermore, the increase in prevalence of the virus in fish groups from fresh to seawater (Figure 2) is in agreement with others that virus contamination in seawater is on the increase (Murray et al., 2003). The results also suggest that brood stations are not important sources of IPNV and the testing program used may be a useful means of maintaining the clean status in the supply of breeding materials.

\section{REFERENCES}

Arnold, K., Bordoli, L., Kopp, J., and Schwede, T. (2006). The SWISSMODEL workspace: a web-based environment for protein structure homology modelling. Bioinformatics 22, 195-201. doi: 10.1093/bioinformatics/bti770

Bain, N., Gregory, A., and Raynard, R. S. (2008). Genetic analysis of infectious pancreatic necrosis virus from Scotland. J. Fish Dis. 31, 37-47. doi: 10.1111/ j.1365-2761.2007.00864.x

Bauer, P. H., Bronson, R. T., Fung, S. C., Freund, R., Stehle, T., Harrison, S. C., et al. (1995). Genetic and structural analysis of a virulence determinant in polyomavirus VP1. J. Virol. 69, 7925-7931.

Betts, M. J., and Russell, R. B. (2003). Amino Acid Properties and Consequences of Substitutions, Vol. 317. Oxford, UK: John Wiley \& Sons.

Bruslind, L. D., and Reno, P. W. (2000). Virulence comparison of three buhlsubtype isolates of infectious pancreatic necrosis virus in brook trout fry. J. Aquat. Anim. Health 12, 301-315. doi: 10.1577/1548-8667(2000)012< 0301:VCOTBS $>2.0 . \mathrm{CO} ; 2$

Coulibaly, F., Chevalier, C., Delmas, B., and Rey, F. A. (2010). Crystal structure of an Aquabirnavirus particle: insights into antigenic diversity and virulence determinism. J. Virol. 84, 1792-1799. doi: 10.1128/JVI.01536-09
In contrast, the absence of IPNV and consequently IPN outbreaks in at least one fish group throughout this study suggests that not all fresh- and seawater sites are contaminated or it is possible to reduce/eradicate IPNV at rearing sites.

The two clades in the phylogenetic tree of the isolates in this study fit very well with the clinical symptoms that the virus induces in Atlantic salmon. Clade 1 was associated with isolates causing overt disease while Clade 2, subclinical infections (Figure 3). Furthermore, the clustering together of isolates from hatcheries and corresponding seawater sites of the same fish groups offers support to the understanding that seawater infections are a recurrence of freshwater infections (Roberts and Pearson, 2005). The clustering together of isolates from one site, renders support to the theory of the existence of "house strains." Finally, it is noteworthy that the findings in this report relate to Norwegian isolates of IPNV. In Ireland and Scotland, IPNV isolates with $\mathrm{P}_{217} \mathrm{~T}_{221}$ motifs were associated with clinical outbreaks (Bain et al., 2008; Ruane et al., 2009, 2015). The explanation for this contradiction is not easy to provide although an interesting subject for future research. Most likely other factors besides virulence as it relates to the virulence motif of IPNV play a role in the outcome of infections.

\section{AUTHOR CONTRIBUTIONS}

Conceived and designed the experiments: SM, ØE, TJ, GR. Performed the experiments: TJ, SM, HM. Contributed reagents/materials/analysis tools: ØE, GR. Analyzed results, discussed and wrote the paper: SM, TJ, GR, HM, ØE

\section{ACKNOWLEDGMENTS}

The Research Council of Norway (Norges Forskningsråd) funded this work (Project number 152043/120). The authors would like to thank Dr. Jon Bohlin for his assistance with phylogenetic analysis.

Dorson, M., and Torchy, C. (1985). Experimental Transmission of Infectious Pancreatic Necrosis Virus via the Sexual Products. London: Academic Press.

Duncan, R., Nagy, E., Krell, P. J., and Dobos, P. (1987). Synthesis of the infectious pancreatic necrosis virus polyprotein, detection of a virus-encoded protease, and fine structure mapping of genome segment a coding regions. J. Virol. 61, 3655-3664.

Frost, P., Håvarstein, L. S., Lygren, B., Stahl, S., Endresen, C., and Christie, K. E. (1995). Mapping of neutralization epitopes on infectious pancreatic necrosis viruses. J. Gen. Virol. 76(Pt 5), 1165-1172. doi: 10.1099/0022-1317-76-5-1165

Gadan, K., Sandtro, A., Marjara, I. S., Santi, N., Munang'andu, H. M., and Evensen, O. (2013). Stress-induced reversion to virulence of infectious pancreatic necrosis virus in naive fry of Atlantic salmon (Salmo salar L.). PLoS ONE 8:e54656. doi: 10.1371/journal.pone.0054656

Galloux, M., Chevalier, C., Henry, C., Huet, J. C., Costa, B. D., and Delmas, B. (2004). Peptides resulting from the pVP2 C-terminal processing are present in infectious pancreatic necrosis virus particles. J. Gen. Virol. 85(Pt 8), 2231-2236. doi: 10.1099/vir.0.80012-0

Gamil, A. A., Evensen, O., and Mutoloki, S. (2015). Infection profiles of selected aquabirnavirus isolates in CHSE cells. PLoS ONE 10:e0134173. doi: 10.1371/journal.pone. 0134173 
Gregory, A., Munro, L. A., Wallace, I. S., Bain, N., and Raynard, R. S. (2007). Detection of infectious pancreatic necrosis virus (IPNV) from the environment in the vicinity of IPNV-infected Atlantic salmon farms in Scotland. J. Fish Dis. 30, 621-630. doi: 10.1111/j.1365-2761.2007. 00844.x

Gregory, A., Raynard, R. S., and Stagg, R. (2003). “Transmission and reservoirs," in IPN in Salmonids-A Review, eds O. Evensen, E. Rimstad, R. Stagg, E. Brun, P. Midtlyng, B. Skjelstad, L. H. Johansen, and I. Jensen (Trondheim: FHL havbruk), 35-50.

Heppell, J., Berthiaume, L., Corbin, F., Tarrab, E., Lecomte, J., and Arella, M. (1993). Comparison of amino acid sequences deduced from a cDNA fragment obtained from infectious pancreatic necrosis virus (IPNV) strains of different serotypes. Virology 195, 840-844. doi: 10.1006/viro.1993.1441

Houston, R. D., Gheyas, A., Hamilton, A., Guy, D. R., Tinch, A. E., Taggart, J. B., et al. (2008). Detection and confirmation of a major QTL affecting resistance to infectious pancreatic necrosis (IPN) in Atlantic salmon (Salmo salar). Dev. Biol. (Basel) 132, 199-204. doi: 10.1159/000317160

Hsu, Y. L., Chen, C. C., and Wu, J. L. (1995). Molecular relationships in infectious pancreatic necrosis virus. Virus Res. 37, 239-252. doi: 10.1016/01681702(95)00035-O

Jones, D. T., Taylor, W. R., and Thornton, J. M. (1992). The rapid generation of mutation data matrices from protein sequences. Comput. Appl. Biosci. 8, 275-282. doi: 10.1093/bioinformatics/8.3.275

Kumar, S., Stecher, G., and Tamura, K. (2016). MEGA7: Molecular Evolutionary Genetics Analysis Version 7.0 for bigger datasets. Mol. Biol. Evol. 33, 1870-1874. doi: 10.1093/molbev/msw054

Liu, C., Eichelberger, M. C., Compans, R. W., and Air, G. M. (1995). Influenza type A virus neuraminidase does not play a role in viral entry, replication, assembly, or budding. J. Virol. 69, 1099-1106.

Macdonald, R. D., and Dobos, P. (1981). Identification of the proteins encoded by each genome segment of infectious pancreatic necrosis virus. Virology 114, 414-422. doi: 10.1016/0042-6822(81)90222-1

Mulcahy, D., and Pascho, R. J. (1984). Adsorption to fish sperm of vertically transmitted fish viruses. Science 225, 333-335. doi: 10.1126/science.6740314

Munro, E. S., and Midtlyng, P. J. (2011). Infectious Pancreatic Necrosis and Associated Aquatic Birnaviruses, Vol. 3. Wallingford, UK: CABI.

Murray, A. G., Busby, C. D., and Bruno, D. W. (2003). Infectious pancreatic necrosis virus in Scottish Atlantic salmon farms, 1996-2001. Emerg. Infect. Dis. 9, 455-460. doi: 10.3201/eid0904.020311

Okamoto, N., Tayama, T., Kawanobe, M., Fujiki, N., Yasuda, Y., and Sano, T. (1993). Resistance of a rainbow trout strain to infectious pancreatic necrosis. Aquaculture 117, 71-76. doi: 10.1016/0044-8486(93) 90124-H

Palese, P., Tobita, K., Ueda, M., and Compans, R. W. (1974). Characterization of temperature sensitive influenza virus mutants defective in neuraminidase. Virology 61, 397-410. doi: 10.1016/0042-6822(74)90276-1

PyMol (2012). PyMol, v.99 Distributed by DeLano Scientific LLC. Available online at: www.pymol.org
Reno, P. W. (1999). "Infectious pancreatic necrosis and associated aquatic birnaviruses," in Fish Diseases and Disorders, Vol. 3, eds P. T. K. Woo and D. W. Bruno (New York, NY: CABI), 1-54.

Rimstad, E. (2003). "The infectious pancreatic necrosis virus," in IPN in SalmonidsA Review, ed B. Skjelstad (Trondheim: FHL havbruk), 17-36.

Roberts, R. J., and Pearson, M. D. (2005). Infectious pancreatic necrosis in Atlantic salmon, Salmo salar L. J. Fish Dis. 28, 383-390. doi: 10.1111/j.13652761.2005.00642.x

Ruane, N. M., McCarthy, L. J., Swords, D., and Henshilwood, K. (2009). Molecular differentiation of infectious pancreatic necrosis virus isolates from farmed and wild salmonids in Ireland. J. Fish Dis. 32, 979-987. doi: 10.1111/j.13652761.2009.01080.x

Ruane, N. M., McCleary, S. J., McCarthy, L. J., and Henshilwood, K. (2015). Phylogenetic analysis of infectious pancreatic necrosis virus in Ireland reveals the spread of a virulent genogroup 5 subtype previously associated with imports. Arch. Virol. 160, 817-824. doi: 10.1007/s00705-014-2307-9

Santi, N., Vakharia, V. N., and Evensen, O. (2004). Identification of putative motifs involved in the virulence of infectious pancreatic necrosis virus. Virology 322, 31-40. doi: 10.1016/j.virol.2003.12.016

Shivappa, R. B., Song, H., Yao, K., Aas-Eng, A., Evensen, O., and Vakharia, V. N. (2004). Molecular characterization of Sp serotype strains of infectious pancreatic necrosis virus exhibiting differences in virulence. Dis. Aquat. Org. 61, 23-32. doi: 10.3354/dao061023

Smail, D. A., and Munro, E. S. (2008). Isolation and quantification of infectious pancreatic necrosis virus from ovarian and seminal fluids of Atlantic salmon, Salmo salar L. J. Fish Dis. 31, 49-58. doi: 10.1111/j.1365-2761.2007.00866.x

Song, H., Santi, N., Evensen, O., and Vakharia, V. N. (2005). Molecular determinants of infectious pancreatic necrosis virus virulence and cell culture adaptation. J. Virol. 79, 10289-10299. doi: 10.1128/JVI.79.16.10289-10299.2005

Wolf, K., Quimby, M. C., and Bradford, A. D. (1963). Egg-associated transmission of IPN virus of trouts. Virology 21, 317-321. doi: 10.1016/0042-6822(63) 90192-2

Conflict of Interest Statement: ØE, GR, TJ, and SM. 2014. IPN vaccine. United States Patent no. 20140072591. Washington, DC: U.S. Patent and Trademark Office.

The other author declares that the research was conducted in the absence of any commercial or financial relationships that could be construed as a potential conflict of interest.

Copyright (c) 2016 Mutoloki, Jøssund, Ritchie, Munang'andu and Evensen. This is an open-access article distributed under the terms of the Creative Commons Attribution License (CC BY). The use, distribution or reproduction in other forums is permitted, provided the original author(s) or licensor are credited and that the original publication in this journal is cited, in accordance with accepted academic practice. No use, distribution or reproduction is permitted which does not comply with these terms. 